\title{
Az Emberi Jogok Európai Egyezménye, a Szociális Karta és a környezeti jogok
}

\section{BÁNDI GYULA ${ }^{1}$}

Az Emberi Jogok Európai Egyezményét 70 éve fogadták el, ami egyben meghatározza azt is, milyen tárgyi kört fognak át az ott tárgyalt emberi jogok. Az Egyezmény létrejöttének körülményeit, tartalmát és fontosságát számos forrás tárgyalja, nem hagyva kétséget afelöl, milyen történelmi pillanatban, történelmi alapokra épitve volt szükség két évvel az ENSZ hasonló dokumentumát követöen a regionális megjelenésre is, nagyobb hangsúlyt adva az emberi jogok kérdésének azon a kontinensen, amelyik a legközvetlenebbül volt és maradt abban az idöszakban is érintett.

Kulcsszavak: Emberi Jogok Európai Egyezménye, környezetvédelem, környezeti jogok, Szociális Karta, bírói joggyakorlat - környezeti jogok

\section{The European Convention on Human Rights, the Social Charter and Environmental Rights}

The European Convention on Human Rights has been in force for 70 years, which also defines the scope of the human rights discussed there. The circumstances, content and importance of the Convention have been discussed by a number of sources, leaving no doubt as to the historic moment at which a regional appearance was needed two years after a similar UN document, with greater emphasis on human rights on the continent that was and remained most directly affected during that period.

Keywords: European Convention on Human Rights, environment, environmental rights, social charter, case law

1 Tanszékvezető egyetemi tanár, Pázmány Péter Katolikus Egyetem Jog- és Államtudományi Kar, e-mail: bandi.gyula@jak.ppke.hu 


\section{Elözmények}

A környezetvédelem újkori történetével sokan foglalkoztak, aki tehát alaposabban kívánja megismerni ennek alapjait, azt megteheti könnyen. Egy találomra kiválasztott oktatási anyag ${ }^{2}$ a környezetvédelem történetét négy nagy korszakra bontja:

1. A környezetvédelem előtörténete;

2. A rádöbbenés korszaka (1960-as évek);

3. A környezetvédelem intézményesülésének, hivatalos elismerésének korszaka (1970-es évek);

4. A hatékony intézkedések, programok, nemzetközi együttmüködések korszaka (1980-as évektől).

A második - rádöbbenés - korszakról ezt írja: „A lakosság környezeti értékelésében az 1960-as évek elején következett be változás. Az első, az egész világon hatalmas megdöbbenést okozó felfedezés az volt, amikor kiderült, hogy az általánosan alkalmazott rovarirtó szerek (DDT, HCH) hosszú időn keresztül nem bomlanak le, így az élő szervezetekben (köztük az emberben is) felhalmozódnak és egészségkárosodást, súlyosabb esetben rákot okoznak." Talán említést érdemel, hogy a kérdéses DDT alkalmazása kapcsán írt kötet - Rachel Carson Néma tavasz címü műve - 1962-ben jelent meg, és máig ható jelentőségű volt. ${ }^{3}$

A környezetvédelem e szakaszának rövid áttekintését az Alkotmánybíróság is fontosnak tartotta az Alaptörvény elfogadását követő első, a megváltozott, új helyzetben meghatározó jelentőségű határozatában, ${ }^{4}$ mintegy a maga és minden érintett számára kijelölve a további vizsgálódás alapjait: „[69] 1. Bár a természeti környezet egyes gazdasági- vagy létfenntartási szempontból fontos elemeinek (erdők, vizek, vadászat, halászat) törvényi védelme évezredes múltra tekint vissza, a mai értelemben vett átfogó környezetvédelmi szemléletről, gondolkodásról és értékrendről csak a 20. század 70-es éveitől beszélünk. Ennek kiváltó okai: a népességrobbanás, a gyors ipari termelésbővülés és fogyasztásnövekedés, a szennyezőanyag-kibocsátás és hulladéktermelés, természetidegen vegyi anyagok használata, a természeti javak visszafordíthatatlan károsítása, illetve felélése. Összefoglalóan: a biológiai értelemben vett élet (az élővilág) - részeként az emberi élet - természeti alapjainak veszélyeztetése és károsítása." Majd e bevezető gondolatokat követően több pontban - a [70] ponttól a [78] pontig - felvázolta a fejlödés föbb menetét, visszacsatolva a gondolatmenetet a határozat érdemi részéhez a következőképpen: „[79] A felvázolt fejlődésvonalba szervesen, sőt úttörő módon illeszkedett a magyar törvényhozás és az alkotmányos jogfejlődés is.”

\footnotetext{
Lásd: http://kornyezetvedelem.ektf.hu/hu/html_files/tudomanytortenet/tudomanytortenet.html A kötet letölthető: https://gutenberg-galaxis.hu/rachel-carson-nema-tavasz-pdf/ 16/2015. (VI. 5.) AB határozat.
} 
Az Emberi Jogok Európai Egyezményét ${ }^{5}$ (Egyezmény) a fent felidézett, áttörést jelentő („rádöbbenés”) felismerések előtt egy évtizeddel, 70 éve fogadták el, ami egyben meghatározza azt is, milyen tárgyi kört fognak át az ott tárgyalt emberi jogok. Az Egyezmény létrejöttének körülményeit, tartalmát és fontosságát számos forrás ${ }^{6}$ tárgyalja, nem hagyva kétséget afelől, milyen történelmi pillanatban, történelmi alapokra építve volt szükség két évvel az ENSZ hasonló dokumentumát ${ }^{7}$ követően a regionális megjelenésre is, nagyobb hangsúlyt adva az emberi jogok kérdésének azon a kontinensen, amelyik a legközvetlenebbül volt és maradt abban az időszakban is érintett.

Ha ebben az Egyezményben a környezetvédelmet keressük, aligha találunk rá közvetlenül, sem elfogadásakor, sem azóta. „Az Emberi Jogok Európai Egyezményét 1950-ben írták alá, 1953-ban lépett hatályba, mielőtt a környezeti problémákat felismerték volna és a környezet védelme megjelent volna a nemzetközi jogban. Éppen ezért a környezeti jogok nem lehettek az Egyezmény részei." ${ }^{8}$ Ez azzal sem változott, hogy ma már 15 jegyzőkönyv egészíti ki a rendszert. ${ }^{9}$ A jegyzőkönyvek mellett számunkra különösen fontos lesz az 1961-ben aláírt Európai Szociális Karta (Karta), annak 1996. évi módosításával egyetemben. ${ }^{10}$ Harmadikként pedig még egy emberi jogi egyezmény csatlakozott - Egyezmény a kínzás és az embertelen vagy megalázó büntetések vagy bánásmód megelőzéséről ${ }^{11}$-, amely számunkra nem releváns. Valójában az egyezmények jelentették az Egyetemes Nyilatkozatot, illetve némileg a Polgári és Politikai Jogok Egyezségokmányát, ${ }^{12}$ és a Gazdasági, Szociális és Kulturális Jogok Egyezségokmánya ${ }^{13}$ számos eleme pedig megjelent a Kartában.

Sem az Egyezmény, sem a Karta, sem a jegyzőkönyvek egyike sem foglalkozik tehát környezetvédelemmel közvetlen módon - a közvetett megoldásokra hamarosan rátérek. Világos az Európa Tanács szakértőinek konklúziója: „Sem az Egyezményt, sem a Kartát nem tervezték úgy, hogy a környezet számára általános védelmet jelentsen,

5 1993. évi XXXI. törvény az emberi jogok és az alapvető szabadságok védelméről szóló, Rómában, 1950. november 4-én kelt Egyezmény és az ahhoz tartozó nyolc kiegészítő jegyzőkönyv kihirdetéséről.

6 Pl. Daniel Moeckli - Sangeeta Shah - Sandesh Sivakumaran (eds.): International human rights law. Oxford, Oxford University Press, 2010; Dinah L. Shelton: Regional protection of human rights. Oxford, Oxford University Press, 2010; Thomas Buergenthal: The Evolving International Human Rights System. American Journal of International Law, 100. (2006), 4. 783-807.; Peter Leuprecht: Innovations in the European System of Human Rights Protection: Is enlargement compatible with reinforcement? Transnational law and contemporary problems. In Christina M. Cerna (ed.): Regional human rights system. Routledge, 2014. 313-336; vagy itthon: Kardos Gábor: Emberi jogok európai védelme. In Halmai Gábor - Tóth Gábor Attila (szerk.): Emberi jogok. Budapest, Osiris, 2008. 155-189.; és még hosszan sorolhatnánk.

7 Az ENSZ Emberi Jogok Egyetemes Nyilatkozata 1948. 1.

8 Svitlana Kravchenko - John E. Bonine: Human rights and the environment. Carolina Academic Press, 2008. 23.

9 European Court of Human Rights: Protocols of the European Convention on Human Rights. 1950.

10 1999. évi C. törvény az Európai Szociális Karta kihirdetéséről.

11 Strasbourg, 1987. november 26., kihirdette a 1988. évi 3. törvényerejü rendelet.

12 1976. évi 8. törvényerejű rendelet.

13 1976. évi 9. törvényerejű rendelet. 
és nem biztosítja kifejezetten a megfelelő, csendes és egészséges környezethez való jogot."14

\section{Erőfeszítések a mai napig}

Tekintsük át röviden, mivel is kell szembesülnünk: „Fejlődésre képes minőségük ellenére a nemzetközi emberi jogi egyezmények (az Afrikai Kartát kivéve ${ }^{15}$ ) még ma sem védik a megfelelő és elfogadható környezethez való jogot anélkül, hogy az ne vonatkozna egyes egyének jogaira. Ehelyett olyan emberi jogi nézőpontjuk van, amely elfogadja az élet, egészség, magánélet, illetve vagyoni sérelmeket, ha az egyes egyénekre vonatkozik, a környezetre vonatkozóan azonban nem."16

$\mathrm{Az}$ alapállás formailag azóta sem változott, érdemben nincs napirenden sem az Egyezmény módositása, sem kiegészitése egy újabb jegyzökönyvvel, noha valóban voltak erre lépések, nem túl sok sikerrel. „Az első kísérlet még 1973-ban történt, amikor a német munkacsoport javaslatot tett egy, az Egyezményhez füzendő jegyzőkönyv elfogadására e körben [...] a Miniszterek Tanácsa úgy határozott, hogy nincs közvetlen szükség arra, hogy az Egyezményt az egészséges környezethez való joggal egészítsék ki. Ezt követően számos jogtudós érvelt azért, hogy legyen az Egyezményben környezethez való jog, számos esetben még szöveges javaslatot is adva. 1999-ben, 2003-ban és 2009-ben az Európa Tanács Parlamenti Közgyűlése javaslatot is tett, amelyben a Miniszterek Tanácsát felszólították, hogy szövegezzen kiegészítő jegyzőkönyvet az Egyezményhez, amely az egészséges és élhető környezethez való jogot elismeri. [...] Mindeddig ezen felhívásokra érdemi válasz nem érkezett." ${ }^{17}$

A két utóbbi példát a fenti három kísérlet közül pár szóval bemutatunk. Az első, ${ }^{18}$ 2003-ból javaslatot tett a tagállamoknak (9.2. pont), hogy lehetőleg alkotmányos szinten „ismerjék el az egészséges, élhető és megfelelő környezethez való jogot olyannak, amely az állam objektív kötelezettségeinek egyike", illetve a Miniszterek Tanácsának (10.1. pont), hogy „alakítsanak ki az Emberi Jogok Európai Egyezményéhez egy kiegészítő jegyzőkönyvet, ami elismeri az egyének eljárási jogait a környezetvédelem érdekében, amint azt az Aarhusi Egyezmény is tartalmazza". Az ajánlások tehát az érdemi környezeti jogok tekintetében inkább a tagállamokra vonatkoztak.

14 Council of Europe: Manual on human rights and the environment. CoE Publishing, 2012.

15 African (Banjul) Charter on Human and People's Rights, 1981, amelynek 24 cikke kimondja: „Minden embernek joga van egy általános, kielégítő minőségű környezethez, amely kedvező a fejlődésük számára., lásd: https://au.int/en/treaties/african-charter-human-and-peoples-rights

16 Francesco Carelli: Enforcing a Right to a Healthy Environment in the ECHR System: the 'Cordella v. Italy' Case. Rivista Giuridica AmbienteDiritto.it, (2019), 4. 3.

17 Jonathan Verschuuren: Contribution of the case law of the European Court of Human Rights to sustainable development in Europe. In Werner Scholtz - Jonathan Verschuuren (eds.): Regional Environmental Law: Transregional Comparative Lessons in Pursuit of Sustainable Development. Edward Elgar Publishing Ltd., 2015. 367-368. Council of Europe: Recommendation 1614 (2003): Environment and human rights. 
Az Európa Tanács Parlamenti Közgyülése - azóta világossá vált, hogy hiába ismételten javaslatot tett a környezethez való jog kodifikálására: ${ }^{19}$ „A Közgyülés rámutat arra, hogy az egészséges környezethez való jogot számos nemzeti alkotmány vagy regionális charta már elismerte kisebb vagy nagyobb mértékben, és az Emberi Jogok Európai Bírósága maga is közvetetten alkalmazza az egészséges környezethez való jogot gyakorlatában. [...] Ennek megfelelően a Közgyűlés felhívja a Miniszterek Tanácsát, hogy készítsék el az Európai Emberi Jogi Konvenció kiegészítő jegyzőkönyvét, elismerve az egészséges és élhető környezethez való jogot."

Az Európa Tanács Környezetvédelmi, Mezőgazdasági, Önkormányzati Bizottsága vezetésével a Közgyűlés a fentit megelőzően, 2009-ben hosszan tárgyalta a környezethez való jog kérdését, számos megállapítást és javaslatot téve ennek irányában, mégpedig az „egészséges és élhető” környezethez való jog elismerése érdekében. E javaslatokban ${ }^{20}$ szerepel, egyebek között:

„1. A Parlamenti Közgyűlés erősítse meg elkötelezettségét a környezettel kapcsolatos kérdésekben, elfogadva, hogy nem csupán alapvető joga a polgároknak, hanem kötelezettsége is, hogy egészséges környezetben éljenek. [...]

9. Tudomással van arról, hogy a társadalom, mint egész és minden egyes tagja egészséges és élhető környezetet kell átadjon a jövő generációknak, a generációk közötti szolidaritás szellemében..."

A magyarázat - amelyet José Mendes Bota jegyzett ${ }^{21}$ - kiindulási pontja szerint:

„B.I.1. Az alapvető jogok és a környezet minősége között közeli kapcsolat áll fenn, és ezen jogok élvezetét veszélyeztetheti a környezet romlása. A környezetvédelem alapvető feltétele ezen jogok megvalósulásának. Ez különösen igaz az egészséghez való jogra, a tulajdonjogokra, illetve a személyi és családi élethez való jogokra. Alá kell húzni a környezetvédelmi és más emberi jogok kapcsolatát, mint az információhoz való jog, az igazságszolgáltatáshoz való jog.

2. Ez a közeli kapcsolat a környezet és emberi jogok között világosan utal ezek összefüggésére és elválaszthatatlanságára. [...]

9. Bármennyire ambiciózus és dinamikus is az Európai Emberi Jogi Bíróság jogygyakorlata, meg kell jegyezni, hogy szükségképpen nem lehet teljes az egészséges környezethez való jog biztosítása tárgyában. [...]

19 Council of Europe Parliamentary Assembly: Doc. 12003. Drafting an additional protocol to the European Convention on Human Rights concerning the right to a healthy environment. 11 September 2009.

20 Council of Europe Parliamentary Assembly: Recommendation 1885 (2009) Drafting an additional protocol to the European Convention on Human Rights concerning the right to a healthy environment.

21 Council of Europe Parliamentary Assembly: Doc. 12003. 
10. Az egészséges környezethez való jog felvétele az Emberi Jogok Európai Konvenciójába teszi csak lehetővé az egyéneknek, hogy erre a jogra hivatkozva éljenek a jogorvoslattal, függetlenül más, az Egyezményben feltűnő emberi jogoktól."

Ugyancsak a jelentéstevő magyarázatként és a kötelezettségekre való kifejezett hivatkozás mintegy elvi alátámasztásaként hozzáfüzte: „12. Manapság tanúi vagyunk annak, amit az alapvető jogok negyedik generációjának nevezhetünk, vagy a jogok és kötelezettségek generációjának, amelyek a jövő társadalmára vonatkoznak. [...] Ez egyszerűen csak a generációk közötti szolidaritás." A környezettel kapcsolatos emberi jogokat a harmadik generációs, úgynevezett szolidaritási jogok között tárgyaljuk, egy negyedik generáció megjelenésének gondolata ezért újdonságot jelent, noha az a harmadik generációs jogok esetében sem meglepő, hogy a kötelezettség oldaláról közelítenek.

Azóta érdemi lépések tehát továbbra sem történtek. A legutóbbi fejlemények között említést érdemel az Európa Tanács emberi jogi tanácsosának véleménye ${ }^{22}$ egy évvel ezelőtt, 2019-ben, ami különösen azért meglepő, mert az nem az Európa Tanácsot ösztökéli a környezeti jogok formális elismerésére, hanem a tagállamokat, illetve különösen az ENSZ intézményeit. Némi rövid környezeti elemzésből két következtetést von le: „Elsősorban az a környezeti teher, amelynek nap mint nap ki vagyunk téve emberi jogaink - mint az élet, egészség, otthon - nagyon súlyos és folyamatos sérelméhez vezethetnek; Másodsorban az emberi jogok védelméhez sürgetően komolyan kell vennünk, hogy figyeljünk arra a környezetre, amelyben élünk. [...] Végezetül arra ösztönözném az Európa Tanács tagállamait, hogy támogassák azokat az erőfeszítéseket, amelyek az ENSZ szintjén az egészséges környezethez való jog kifejezett elismerésére irányulnak."

A környezettel kapcsolatos jog észszerủ elvárás mivoltának elvi-etikai alátámasztása érdekében egy-két gondolatot érdemes aláhúzni, szemelvényt kiemelni, mert arra utalnak, hogy a környezettel összefüggő jogok a többi emberi jog megvalósulásához szolgálnak nélkülözhetetlen alapként. Időrendben elsőként hivatkozhatunk az ENSZ 1972-es Stockholmi Környezetvédelmi Világértekezlete 1. számú alapelvére, amely - az életminőséget állítva középpontba egy fogyasztói társadalmi túlsúly ellenében - kimondja: „Az embernek alapvető joga van a szabadsághoz, egyenlőséghez és a megfelelő életfeltételekhez egy olyan minőségủ környezetben, amely emberhez méltó és egészséges életre ad lehetőséget, ugyanakkor pedig ünnepélyes kötelezettsége, hogy e környezetet a jelen és jövő nemzedékek számára megóvja és javítsa."23 Jog és kötelezettség egységben, illetve a klasszikusnak mondható emberi jogok mint kiindulási pont - ezek jellemzik ezt a megközelítést.

22 Human Rights Comment: Living in a clean environment: a neglected human rights concern for all of us. Strasbourg, Council of Europe, 2019. 1.

23 United Nations: Report on the United Nations Conference on the human environment. Stockholm, 5-16 June 1972. 
II. János Pál pápa egy teljes béke világnapi üzenetet szentelt az emberi jogoknak, kiindulási pontnak tekintve - az emberi jogi dokumentumokhoz hasonlóan - az emberi méltóságot, ezért a 10. pont kiváltképpen hangsúlyos lehet: „10. Az emberi méltóság elősegítése az egészséges környezethez való joggal összefügg, mert e jog rávilágít az egyén és a társadalom közötti viszony dinamikájára. Nemzetközi, regionális és nemzeti normák fokozatosan jogi formába öntik ezt a jogot. A jogszabályok azonban önmagukban nem elégségesek."24

Nem csoda tehát, ha az erkölcsi megközelítés egyik meghatározó példájaként a Katolikus Egyház társadalmi tanításának Kompendiuma világosan kijelenti: „A környezetért való felelősségnek megfelelő módon kell jogilag kifejeződnie" és ugyanebben a pontban, az Egyház „a biztonságos és egészséges természeti környezethez való jog" gondolatát mint szükséges realitást emeli ki. ${ }^{25}$

Egy harmadik elvi alap lehet a sok más lehetőségből a Bős-Nagymaros-ügyben Weeremantry különvéleménye: ${ }^{26}$ „A környezet védelme szintén alapvető része az emberi jogok jelenleg érvényes doktrínájának, hiszen számos emberi jognak, így például az egészséghez, illetve az élethez való jognak előfeltétele. Aligha szükséges ezt részletesebben kifejteni, mivel a környezetet ért károk az Egyetemes Nyilatkozatban és egyéb emberi jogi okmányokban említett összes emberi jogot csorbíthatják, illetve alááshatják."

Mindezek tudatában kellene tehát továbbfejleszteni az emberi jogok különféle katalógusait a 21. században.

\section{A bírói joggyakorlat esete a környezeti jogokkal}

Az ENSZ Stockholmi Nyilatkozata már 1972-ben adottnak vesz valamilyen alapjogi vonatkozást, és 20 évvel később, a Riói Nyilatkozat ${ }^{27} 1$. számú alapelve valójában megismétli a fentieket: „Az emberek állnak a fenntartható fejlődés középpontjában. Joguk van az egészséges és produktív életre a természettel harmóniában." Ez persze nem jelenti, hogy az ENSZ emberi jogi rendszere automatikusan befogadta volna ezt az új jogot, de legalább létezik olyan hivatkozás ebben a globális körben, amely használható. Az Afrikai Karta, ${ }^{28}$ mint az európai regionális egyezmények megfelelője, már 1981-ben inkorporálta ezt a jogot, az amerikai San Salvador Jegyzőkönyv ${ }^{29}$ 1988-ban

24 II. János Pál pápa: Az emberi jogok tisztelete az igazi béke titka. Üzenet a béke világnapja alkalmából. (Message of his Holiness Pope John Paul II for the celebration of the World Day of Peace. 1999.)

25 Az Igazságosság és Béke Pápai Tanácsa: Az Egyház társadalmi tanitásának kompendiuma. Budapest, Szent István Társulat, 2007. 468. pont, 236-237.

26 A Nemzetközi Bíróság 1997. szeptember 25-i ítélete, Magyarország és Szlovákia jogvitája, Christopher Weeramantry alelnök különvéleménye.

27 Részletes ismertetést lásd: http://real.mtak.hu/65984/1/1992Rioi_konferencia_1992_u.pdf

28 African (Banjul) Charter on Human and People's Rights, 1981.

29 Additional Protocol to the American Convention on Human Rights - elfogadva az amerikai államok találkozóján, San José, Costa Rica, 1969. Hatályba lépett 1978. július 18-án - in the area of Economic, Social and Cultural Rights "Protocol of San Salvador", elfogadva San Salvadorban (El Salvador) 1988-ban, hatályba lépett 1999. november 16-án. 
pedig így fogalmaz 11. cikkében: „1. Mindenkinek joga van egészséges környezetben élni és a közszolgáltatásokhoz hozzáférni. 2. Az államok hozzájárulnak a környezet védelméhez, megőrzéséhez és javításához." Hol marad tehát Európa?

Az nem is lehetett kétséges, hogy a jogkereső polgárok, akiknek emberi jogi sérelmei közvetlenül vagy némi áttétellel környezeti ártalmakhoz, szennyeződésekhez, veszélyekhez kapcsolódnak, keresik és megtalálják a jogérvényesítés lehetőségét, végső soron, ha a szükség úgy hozza, az európai jogszolgáltatási rendszerben (aminek részleteiről, intézményeiről és eljárásáról nem tisztem szólni). Ez az igény, ez a nyomás mind jobban növekszik, amint a környezeti problémák sokasodnak, nem is beszélve arról, hogy ilyen jogkeresők kiváltképpen ott fordulnak elő nagyobb számmal, ahol a jogbiztonság, jogállamiság még erősítésre vár, illetve ahol a környezetvédelmi jogi szabályozás maga vagy éppen a jogalkalmazás nem mondható példaértékủnek. Az Emberi Jogok Európai Bírósága vonatkozó összegzése ${ }^{30}$ szerint 60 év alatt az ítéletek 40\%-a három országgal volt kapcsolatos - Törökország, az Orosz Föderáció és Olaszország, de Ukrajna vagy Románia is az első öt között található. És az sem lehet kétséges, hogy a jogkeresőket nem tartja vissza az a tény, hogy az Egyezmény vagy a Karta nem sorolja fel a jogok között a környezethez való jogot, bármely minősítő jelzőt - emberhez méltó, egészséges, biztonságos, csendes, zavartalan stb. - is használunk erre. De miért is lenne ez az elmaradó kodifikálás visszatartó erő akkor, amikor a világot évtizedek óta foglalkoztatja a környezeti problémák sora, és az emberi jogi sérelmek egyre nagyobb hányada éppen ennek tudható be?

Ha azonmód bele is vágunk, akkor legjobb egy áttekintéssel kezdeni, ami az elmúlt évtizedek során mára kialakult állapotot tükrözi. Az Emberi Jogok Európai Bizottsága 1982-ben határozott elsőként környezetvédelemhez kapcsolódó témában az Arrondale-ügyben, ${ }^{31}$ amelyben a Gatwick repülőtér müködése kapcsán állapította meg a Bizottság, hogy noha a zajt és az ebből eredő kárt nem az eljárásban az államot képviselő Légügyi Hatóság okozta, de mégis felelős a repülőtér és a kifutók megfelelő tervezéséért és építéséért. Ennek folytatását jelenti nem sokkal később az Emberi Jogok Európai Bíróságának (EJEB, Bíróság) gyakorlata.

Megfordítva kissé a vizsgálatot, kezdeném egy összegzéssel, amelynek eredményeképpen világosabban el kell határolnunk, mivel is foglalkozzunk részletesen, mit tekinthetünk valóban kiemelkedően fontos jogi alapoknak. Az Európa Tanács által kiadott, környezeti jogokra vonatkozó Kézikönyv ${ }^{32}$ a legismertebb olyan hivatkozás, amely az EJEB által időszakonként (legutóbb 2020 márciusában) kiadott összefoglalójának ${ }^{33}$ is megfelelően, az Egyezmény egyes cikkeinek gyakorlatán keresztül bemutatja, miként is jelennek meg a lehetséges környezetvédelmi összefüggések. Ez utóbbi-

30 Erre nézve kiváló statisztikák találhatók az Emberi Jogok Európai Bírósága összegzésében: European Court of Human Rights: Overview 1959-2018. Strasbourg, Council of Europe, 2019.

31 Arrondale v.UK 7889/77.

32 Council of Europe (2012) i. m.

33 European Court of Human Rights: Environment and the European Convention on Human Rights. March 2020. 
nak „mottója” is figyelemre méltó: „Noha az Európai Emberi Jogok Egyezménye nem ismeri el a tiszta környezethez való bármiféle sajátos jogot, az Emberi Jogok Európai Bírósága indíttatást érzett, hogy esetjogát a környezeti ügyek irányában alakítsa, annak a ténynek betudhatóan, hogy az Egyezmény egyes jogainak gyakorlását alááshatja a környezetben okozott kár és a környezeti kockázatoknak való kitettség."

A két anyagból a következö lehetöségeket, egyes emberi jogokat sorolhatjuk fel:

- az élethez való jogot (2. cikk);

- az embertelen vagy lealacsonyító bánásmód (3.cikk);

- szabadság és biztonság (5.cikk);

- a tisztességes eljáráshoz és bírósághoz forduláshoz való jogot (6. cikk);

- a magán- és családi élet, az otthon joga (8. cikk);

- az információs jogok (10. cikk);

- a gyülekezési és egyesülési jog (11. cikk);

- a hatékony jogvédelemhez való jogot (13. cikk), illetve

- a birtoklás zavartalanságához való jogot (1. sz. jegyzőkönyv 1. cikke).

Ugyancsak említést érdemel a Kézikönyv szerint az Európai Szociális Charta 11. cikke, az egészséghez való jog védelméhez kapcsolódóan. De erre külön pontban térek vissza.

Ugyanakkor hiába listázhatunk az Európai Konvencióból több lehetőséget, amelyek a környezethez való jog közvetett védelmében felhasználhatók, mindez nem változtat azon a fent már említett tényen, amit a Kézikönyv maga is megállapít: „Sem a Konvenció, sem a Charta nem szolgál arra, hogy a környezet általános védelmét biztosítsa, és kifejezetten nem garantálják a megfelelő, csendes és egészséges környezethez való jogot. Mindenesetre, mind a Konvenció, mind a Charta közvetett módon lehetőséget ad a környezeti kérdésekkel kapcsolatos bizonyos védelemre, amit jól bizonyít a Bíróság fejlődő esetjoga vagy a Szociális Jogok Bizottságának e téren született határozatai." ${ }^{34}$

Ugyancsak a kézikönyvből kiemelve egy rövid áttekintést: ${ }^{35}$ „A környezeti tényezők az egyének számára biztosított egyezményben biztosított jogokat három különböző úton érinthetik:

- elsősorban a Konvencióban foglalt jogokat közvetlenül sérti a környezeti állapot $[\ldots]$

- másodsorban a környezeti problémák az érintettek számára eljárási jogokat generálhatnak [...]

- harmadsorban a környezetvédelem más emberi jogokba való beavatkozás kapcsán jelenthet jogi alapot."

Mindez azért nyer különös fontosságot, mert az EJEB nem nézhette tétlenül, hogy a nem létező közvetlen jogalap, a nem létező konkrét emberi jog hiányában a 20. szá-

34 Council of Europe (2012) i. m. 7.

35 Council of Europe (2012) i. m. 8. 
zad végén nem lehet foglalkozni környezetvédelmi ügyekkel. Ez nem lenne más, mint a tehetetlenség bizonyítéka, talán nem túlzás azt állítani, hogy a bírák alkalmasságának is fokmérője. Mit tehetünk jogértelmezéssel, analógiával, meddig juthatunk el az emberi jogok tartalmának formálásában? Látni fogjuk azt is, hogy ennek a jogértelmezési gyakorlatnak szükségképpen van határa, ami egyben az Egyezmény jelenleg adott keretei végső határának is tünik.

Az EJEB kezdeményezéseit e téren a szakma osztatlan támogatása kísérte: „Az Emberi Jogok Európai Bírósága nagy aktivitást mutatott a tiszta és egészséges környezethez való jog a létező polgári és politikai jogok közötti megformálása terén”, illetve „[a] bíróság közvetett módon élesztette fel a környezeti jogokat, saját jogértelmezésén keresztül, a más jogoknak biztosított védelem alkalmazásával”. ${ }^{36}$ „Annak ellenére, hogy az Emberi Jogok Európai Egyezményének rendelkezéseit nem kifejezetten a környezet védelmére tervezték, az egyének alkalmanként kereshetik az igazságukat a környezeti kérdésekben, keresetüket az EJEB (Strasbourg) elé terjesztve. És nem egyszer sikeresen." ${ }^{37}$ "Ami a közös ezekben a kezdeményezésekben, az nem mást, mint az a cél, hogy segítse az emberek érdekeit érvényesülni olyan téren, mint az egészség, a jólét vagy a szennyezés különböző formáinak elkerülése; Olyan cél, amely nem tér el igazán az emberi jogoktól." ${ }^{38}$ Ugyanitt, a konklúziók között: „Alappal feltételezhetjük, hogy az Egyezmény kiterjesztése egyes környezeti kérdésekre nem annyira ellentmondásos, és jól illeszkedik az Egyezmény intézményeinek érdekei közé, amelyek hatékony Egyezményt szeretnének látni, amelyik reagál a társadalmi kihívásokra." ${ }^{39}$

Visszatérve a fenti felsoroláshoz, jelen tanulmány keretében nem tárgyalhatom valamennyi cikkhez kapcsolódó joggyakorlatot, annál is inkább, mert nem is lenne erre szükség. A felsorolt cikkek érintettsége nem egy esetben csak marginális, és akkor sem egyedül, hanem más - mondhatni, karakterisztikusabb - cikkekkel együtt jelenik meg. Nem mondható jellemzőnek tehát a 3. cikk és az 5. cikk. A további cikkek joggyakorlata két alapvető szempont köré csoportosítható: a) a környezethez kapcsolható érdemi emberi jogi kérdések - a szubsztancia -, vagy másként a környezetvédelem és emberi jogi kapcsolat anyagi joga. A 2. cikk, az. 1. számú jegyzőkönyv 1. cikke és különösképpen a 8. cikk sorolható ebbe a körbe, és bizony e körben a jogértelmezésnek sok akadályt kell leküzdenie; b) a környezetvédelmi érdekek érvényesülését elösegitö eljárásjogi kérdések: a 6. cikk, 10. cikk, 11. cikk és a 13. cikk. Az eljárásjogi keretek helyzete egyszerủbb, a kapcsolódás a meglévő jogokhoz gyakorlatilag evidencia.

36 Malgosia Fitzmaurice: Environmental Degradation. In Moeckli-Shah-Sivakumaran (eds.) (2010) i. m. 628.

37 Building expertise, sharing good practises, improving access to justice in environmental matters - 161 Italian citizens won before the European Court of Human Rights, News / 6 February 2019, Analysis from Malgorzata Kwiedacz-Palosz, ClientEarth (Official page of the ATOJ EARL project, funded by the European commission LIFE programme Access to justice for a Greener Europe).

38 Ole W. Pedersen: The Ties that bind: The environment, the European Convention on Human Rights and the Rule of Law. European Public Law, 16. (2010), 4. 571-595.

Pedersen (2010) i. m. 36-37. 
A következőkben elsősorban az első, anyagi joginak mondott, kérdésekre fordítok figyelmet, röviden említést téve csupán az eljárási jogi jellegű jogokról. Ehhez érdemes felidézni a kérdéses három cikket: ${ }^{40}$

\section{„2. cikk: Élethez való jog}

1. A törvény védi mindenkinek az élethez való jogát. Senkit nem lehet életétől szándékosan megfosztani, kivéve, ha ez halálbüntetést kiszabó bírói ítélet végrehajtása útján történik, amennyiben a törvény a büncselekményre ezt a büntetést állapította meg.

8. cikk: Magán- és családi élet tiszteletben tartásához való jog 1. Mindenkinek joga van arra, hogy magán- és családi életét, lakását és levelezését tiszteletben tartsák.

2. E jog gyakorlásába hatóság csak a törvényben meghatározott, olyan esetekben avatkozhat be, amikor az egy demokratikus társadalomban a nemzetbiztonság, a közbiztonság vagy az ország gazdasági jóléte érdekében, zavargás vagy büncselekmény megelőzése, a közegészség vagy az erkölcsök védelme, avagy mások jogainak és szabadságainak védelme érdekében szükséges.

\section{1. sz. jegyzőkönyv}

1. cikk - Tulajdon védelme

Minden természetes vagy jogi személynek joga van javai tiszteletben tartásához. Senkit sem lehet tulajdonától megfosztani, kivéve, ha ez közérdekből és a törvényben meghatározott feltételek, valamint a nemzetközi jog általános elvei szerint történik."

\subsection{A 8. cikk}

A három kiemelt cikk közül a 8. cikkel kezdem, hiszen ez jelenti az EJEB-joggyakorlat legnagyobb részét (az idén márciusi „factsheet” - amely minden cikkre kitér - felét elfoglalva), illetve ebben tér el talán legjobban az adott cikk eredetileg tervezett céljaitól, érdemben és jelentősen tágítva azokat. Egyebekben pedig a 8 cikk gyakran szerepel a már jelzett más cikkek mellett hivatkozási alapként. Ha valakit a 8. cikk mostani állapotának kialakulási története érdekel, az elolvashatja azt Pedersennél. ${ }^{41}$

40 1993. évi XXXI. törvény az emberi jogok és az alapvető szabadságok védelméről szóló, Rómában, 1950. november 4-én kelt Egyezmény és az ahhoz tartozó nyolc kiegészítő jegyzőkönyv kihirdetéséről

41 Pedersen (2010) i. m. 
A 8. cikk jelen értelmezését a már említett Arrondale-ügy kezdte, de érdemben az első a López Ostra v. Spanyolország ügy ${ }^{42}$ volt. A López Ostra-eset egy, a panaszosok lakása közvetlen közelében lévő, illegális szilárd és folyékony hulladékokat kezelő létesítmény által okozott környezeti károkra alapozódott. A tényállás rövid tartalma emellett a spanyol hatóságok és bíróságok elmarasztalására is irányul, amelyek nem tettek meg mindent a panaszosok védelme érdekében. A Bíróság elfogadta az Emberi Jogok Európai Konvenciójának 8. cikkét mint jogalapot, amely a magán- és családi élet védelmét szolgálja. Az állam felelősségét - amelyet a 8. cikk 2. bekezdése követel meg - pedig nem aktív magatartásban, hanem abban látták, hogy valóban nem védte meg a panaszosokat, mert az állam részéről a jogsértés nem csupán az aktív beavatkozásban, hanem annak hiányában is áll. A konklúzió a 8. cikk tekintetében: „58. Figyelemmel a fentiekre, nem feledkezve meg az érdekelt állam számára nyitva álló cselekvési (mérlegelési) lehetőségekről, a Bíróság úgy találja, hogy az államnak nem sikerült megfelelő egyensúlyt találnia a város gazdasági jóléte - hogy tehát legyen hulladékkezelő létesítménye - és a kérelmező azon igénye között, hogy megfelelően élvezze az otthon, illetve magán- és családi élet tiszteletét." A kérelmezők a listánkban ugyancsak felsorolt 3. cikkre is hivatkoztak, amit a Bíróság nem talált megalapozottnak. „60. [...] Azok a körülmények, amelyek között a család az évek során élt valóban nagyon nehezek voltak, de nem érték el az embertelen bánásmód 3. cikkbeli értelmét."

Hasonlóan végződött a másik ismert esetben - Guerra és társai v. Olaszország (a határozat 1998. február 19-én született) - a Manfredoniában élő 420 lakos panasza az Enichem mezőgazdasági kemikáliákat előállító üzem szennyezésével kapcsolatban. Valójában az olasz kormány már régóta foglalkozott a helyzettel, de - akárcsak Spanyolországban - nem történt semmi érdemleges, noha még polgári és büntetőjogi eljárásokat is indítottak, de ezek sem hoztak eredményt. Két cikk volt a hivatkozási alap: az információ megismerése és közlése, tehát a 10. cikk. Ezzel kapcsolatban a határozat leszögezi, hogy: „53. [...] Ez a szabadság nem jelenti azt, hogy az államot - olyan körülmények között, mint a jelenlegi eset - pozitív irányú kötelezettség terhelné, hogy saját elhatározásából gyűjtsön és közreadjon információkat." A 8. cikk viszont megállja a helyét, mert a toxikus anyagok kibocsátása a családi és magánélet veszélyét jelenti. Ismét bebizonyosodott, hogy az államnak vannak pozitív kötelezettségei is az ilyen jogok védelmére. ${ }^{43}$

A Bíróság ezen ítéleteket követően több hasonló ügyet tárgyalt, amelyekből az elsőt tíz évvel követő Fadeyeva-ügy ${ }^{44}$ az, ami voltaképpen egyben összegzi is az eddigieket. A kérdéses ügyben felperesek szintén a 8. cikkre hivatkoztak, az otthonuk közelében lévő fémfeldolgozó üzem egészséget és jólétet veszélyeztető mivolta miatt. A megállapítások legfontosabbjai: „70. Ennek megfelelően, a 8. cikkely érintettsége megállapításához a környezeti zavarással összefüggésben be kell bizonyítani,

42 López Ostra v. Spain, Application no. 16798/90. A határozatot 1994. december 9-én fogadták el.

43 Guerra v. Italy (116/1996/735/932) 1998. ítélet 58. pont.

44 Fadeyeva v. Russia (55723/00) határozat, 2005. június 9-én. 
hogy először a felperes magánszférájába történt tényleges beavatkozás, másodszor, hogy a súlyosság bizonyos szintjét is elérték." A hatóságok felelőssége az adott ügyben abban áll, hogy lehetőségük volt értékelni a káros hatást és megtenni a szükséges intézkedéseket ezek megelőzése és csökkentése érdekében (92.). A Bíróság azt is megállapította, hogy a környezetvédelem egyre növekvő módon a közérdeklődés homlokterébe került. Ennek következtében az államok az ipari tevékenységek káros hatásainak csökkentésére számos megoldást fogadtak el. Ugyanakkor minden ilyen ügyben a nemzeti hatóságok nyilvánvaló hibáját, mulasztását kell megtalálni, amikor a különböző magánérdekek közötti versengő érdekek közötti egyensúly kialakítására törekednek. Jelen esetben az állam nem biztosított semmilyen hatékony megoldást annak érdekében, hogy a felperes elköltözhessen erről a területről, sőt nem is látszik, hogy tervezne olyan intézkedést, amely a helyi lakosok érdekében állana, és a szenynyezés elfogadható korlátok közé szorítását célozná (133.). Így, noha az államnak széles körű mérlegelési joga van az intézkedésre, mégsem próbálta meg a megfelelö egyensúlyt kialakítani a közösség és a felperes érdekei védelmében, amely az otthon és a személyes élet megfelelő élvezetét hatékonyan biztosíthatná (134.).

A fenti - és számos más - mellett a Moreno Gomez-ügy ${ }^{45}$ megfogalmazása is kiemelt jelentőségü:

„53. A Konvenció 8. cikke az egyének jogait védi a magán- és családi élet tekintetében, az otthon és a levelezés kérdésében. Az otthon általában az a hely, amely fizikailag körülírható és ahol a magán- és családi élet fejlődik. Az egyénnek joga van otthonának tiszteletben tartására, nem csupán a tényleges fizikai terület vonatkozásában, hanem e terület csendes élvezetében. Az otthon tiszteletben tartásához való jog megsértése nem korlátozható konkrét vagy fizikai sérelmekre, mint egy arra fel nem hatalmazott személy belépése a személy otthonába, hanem olyan sérelmeket is takar, amelyek nem konkrétak és nem fizikaiak, mint a zaj, a szennyezőanyag-kibocsátás, szag vagy a zavarás más formája. Egy súlyos jogsértés a személy otthonának tiszteletben tartására vonatkozó jogát sértheti meg, mert megakadályozza az otthon előnyeinek élvezetében." A következtetés pedig már ismert: „57. Jelen ügyben nem a közigazgatási szervek beavatkozása jelent meg az otthon tekintetében, hanem ezek abbéli mulasztása, hogy nem léptek fel a kérelmező jogainak harmadik személy általi megsértése ellenében. [...] 62. Ezen körülmények között a Bíróság úgy találja, hogy az alperes állam nem teljesítette pozitív irányú kötelezettségét a kérelmező otthonához és magánéletéhez való jogának biztosítása érdekében, a Konvenció 8. cikkét megsértve.”

A továbbiakban csak egyes jellemző pontokat emelek ki egyes meghatározó ítéletekből, de ennek előtte mindenképpen szólnunk kell a két magyar vonatkozású ügyről, amelyekben voltaképpen az EJEB vonatkozó gyakorlatának alapvető megállapításait

45 Moreno Gomez v. Spain (4143/02), 2005. február 16. 
összegzik. Az egyik (Deés) az M5 autópálya létesítése kapcsán megnövekedett jármüforgalommal összefüggésben került Strasbourgba, ${ }^{46}$ és a kérelmező javára hozott eredményt. ${ }^{47} \mathrm{~A}$ másik a MÁV által előidézett megemelkedett zajszintre alapozott ügy (Bor) volt, ${ }^{48}$ amelynek ítéletét kiválóan lehet felhasználni az EJEB eljárására irányadó legfontosabb jellemzők bemutatására, hiszen addigra számos tapasztalat halmozódott fel, amelyeket itt összegezve látunk:

„24. A Bíróság emlékeztet arra, hogy az Egyezmény nem biztosit kifejezett jogot a csendes környezethez, de ha egy egyént közvetlen módon és súlyosan érint valamilyen zaj, akkor felmerülhet a 8. cikk alá tartozó kérdés [...] Attól függetlenül, hogy az ügy az állam arra vonatkozóan fennálló pozitív kötelezettsége szempontjából kerül elemzésre, hogy minden észszerủ és megfelelő intézkedést megtegyen a kérelmező 8. cikk 1. bekezdése alapján fennálló jogainak biztosítására, vagy pedig abból a szempontból kerül megvizsgálásra, hogy a hatósági beavatkozás a 2. cikk alapján igazolt volt-e, az alkalmazott elvek nagyon hasonlóak. Mindkét összefüggésben figyelemmel kell lenni arra, hogy megfelelő egyensúlyt kell teremteni az egyén, illetve a közösség egészének versengő érdekei között; s mindkét kontextusban az állam bizonyos terjedelmủ mérlegelési jogkörrel rendelkezik az Egyezménynek való megfelelés biztosítása érdekében megteendő lépések meghatározása során. Továbbá, a szükséges egyensúly megteremtése során a 8. cikk 2. bekezdésében említett céloknak még az 1 . bekezdésből fakadó pozitív kötelezettségek_vonatkozásában is lehet relevanciája. [...] A Bíróság korábban már megállapította, hogy a jogszabályban lefektetett határértékeket jelentősen meghaladó olyan zaj, amellyel kapcsolatosan a kormány nem tett megfelelő válaszintézkedéseket önmagában is az Egyezmény 8. cikke megsértésének minősülhet."

Tovább folytatva az alapkérdések összegzését:

„27. A Bíróság elfogadja, hogy a 8. cikkben biztosított jogok védelmére hivatott szabályozási és egyéb intézkedések meghatározása során az Egyezménynek való megfelelés biztosítása érdekében megteendő lépések kiválasztása terén az állam bizonyos terjedelmü mérlegelési jogkörrel rendelkezik (ld. fent hivatkozott Deés kontra Magyarország, 23. bekezdés). Hangsúlyozza azonban, hogy a szankciórendszer megléte nem elegendő, ha az nem kerül megfelelő időben és hatékonyan alkalmazásra. Ezzel kapcsolatosan a Bíróság ismételten felhívja a figyelmet arra a tényre, hogy a hazai hatóságok tizenhat éven keresztül semmilyen végrehajtandó

46 Deés v. Magyarország ügy, (2345/06. sz. kérelem), 2010. november 9.

47 „24. Ilyen körülmények között a Bíróság úgy véli, hogy közvetlen és súlyos zavarás állt fenn, amely érintette azt az utcát, amelyben a kérelmező él, és a szóban forgó időszakban megakadályozta a kérelmezőt otthonának élvezetében. A Bíróság úgy találja, hogy az alperes Állam nem teljesítette azon pozitív kötelezettségét, hogy garantálja a kérelmező lakásának és magánéletének tiszteletben tartásához füződő jogát. Ezért az Egyezmény 8. cikkét megsértették."

Bor v. Magyarország (50474/08. sz. kérelem), 2013. június 18. 
intézkedésről nem határoztak annak érdekében, hogy a kérelmező ne szenvedjen aránytalan egyéni terhet.

28. Ezért a Bíróság azt a következtetést vonja le, hogy az állam nem tett eleget a kérelmezőt az otthona tiszteletben tartása tekintetében megillető jog biztosításával kapcsolatos pozitív kötelezettségének. Ezért az Egyezmény 8. cikkét megsértették." ${ }^{49}$

Ígéretemhez híven most már csak egyes, eddig kevésbé vagy nem tárgyalt vonatkozásokra hívnám fel a figyelmet a számos jogesetből, méghozzá időrendben:

- A Heathrow repülőtér éjszakai repülések miatt indult eljárásában ${ }^{50}$ (Hatton) ismét az állam pozitív kötelezettségei kerültek szóba, ahol a kötelezettségekre vonatkozóan az EJEB megállapítja: „119. [...] a környezeti ügyekben az állam felelőssége abban is megmutatkozhat, hogy nem szabályozza megfelelően a magángazdaságot, olyképpen, ahogy azt az Egyezmény 8. cikke elvárja." A kérdés tehát az állam kötelezettségei mellett a gazdasági és környezeti érdek közötti egyensúly megtalálása is. Figyelemmel azonban az állam folyamatos lépéseire, a pozitív kötelezettség hiánya nem volt megállapítható. A 96. pont kiemeli, hogy „[n]incs az Egyezményben a tiszta és csendes környezetre vonatkozó jog, noha amennyiben egy egyén közvetlenül és súlyosan érintett a zaj vagy más szennyezés által, a 8. cikkre hivatkozhat". Különösen fontos kérdésre világít rá ismét az EJEB, amikor aláhúzza: „97. Ugyanakkor a Bíróság ismételten felhívja a figyelmet az Egyezmény alapvetően szubszidiárius szerepére. A nemzeti hatóságoknak közvetlen demokratikus felhatalmazásuk van és emellett - amint erre a Bíróság rámutatott több esetben - jobb helyzetben is vannak, mint egy nemzetközi bíróság annak megítélésében, milyenek a helyi szükségletek és feltételek."

- A környezet védelme jelentősen erősödő szempont, ami a közösség, és éppen ezért a közigazgatási hatóságok érdeke is egyben (Hamer). „A pénzügyi szempontok és még egyes más alapjogok sem - mint a tulajdon - nem kaphatnak prioritást a környezetvédelmi megfontolásokkal szemben [...] a hatóságoknak ezért feltételezzük a felelősségét." ${ }^{51}$

- Miközben nem találta befogadhatónak a kérelmet (Furlepa), az EJEB az elutasításon belül tett néhány fontos értelmezési megjegyzést tesz vagy ismétel meg az egész megközelítés érdemére nézve: ${ }^{52}$ „[E]zzel összefüggésben a Bíróság emlékeztet arra, hogy nincs az Egyezményben a tiszta és csendes környezetre vonatkozó jog, noha amennyiben egy egyén közvetlenül és súlyosan érintett a zaj vagy más szennyezés által, a 8 . cikkre hivatkozhat [...] ami a súlyos környezeti szennyezéssel összefüggésben merülhet fel, amikor az érinti az egyén jólétét

49 Bor v. Magyarország 27. és 28. bek.

50 Hatton v. UK (Application no. 36022/97), 8 July 2003.

51 Hamer v. Belgium (Application no. 21861/03), 27 November 2007. 79. pont.

52 Furlepa v. Poland (Application no. 62101/00), 18 March 2008. 
és megakadályozza otthona élvezetében oly módon, ami magán- és családi életét hátrányosan érinti, anélkül is, hogy egészségét súlyosan veszélyeztetné."

- A bíróság nem vonta kétségbe, hogy lennie kell egy olyan európai vagy egyetemes felfogásnak, amely védi a kulturális örökséget (Ahunbay). Mindez ma a kisebbségek, őslakosok jogaival összefüggésben létezik a jogvédelem szintjén. Ilyen általános egyéni jog nincs..$^{53}$

- Az egyik legutóbbi jelentôs ügy ${ }^{54}$ (Cordella) az olasz Ilva acélmű szennyezését ismerte el olyannak, amely 180 panaszos, illetve az egész környék életét megnehezítette, és ahol az állam nem teremtette meg a közérdek és az egyéni érdek közötti megfelelö egyensúlyt.

\subsection{A 2. cikk}

Talán nem túlzás azt állítani, hogy a 8. cikk és a 2. cikk alkalmazása közötti egyetlen igazi különbség, hogy az utóbbi esetben sajnálatos módon haláleset is bekövetkezett, amivel az egyébként jobbára azonos tartalom egy fokozottabban súlyos szintre jutott. Az alapok - tehát az okozat, az állam kiemelt felelőssége, mégpedig pozitív irányban megnyilvánuló lépések révén - itt is megjelennek. A hatás súlyossága e téren sajnálatos módon adott. Az is lényegi elem, hogy a 8. cikk valójában szinte minden esetben együtt értelmezhető a 2. cikkel, bár a hangsúly itt eltérő.

A legismertebb - lévén érdemben első ebben a tárgykörben - jogeset az Öneryildiz v. Törökország eset, ${ }^{55}$ amelyben egy 1993. április 28-i baleset játszott föszerepet. A tényállás szerint a panaszosok családjának egyes tagjai - és sokan mások - halálát okozta egy Isztambul külvárosában működő nem megfelelő műszaki állapotú hulladéklerakó, amely több évtizede a hatóságok jóváhagyásával működött. A lerakóban felgyülemlő metángáz robbanása következtében a lerakó egy része, illetve vele a domboldal leomlott az alant fekvő nyomornegyed házaira, 39 emberre végzetesen. A lerakó műszaki állapotát már korábban is kifogásolták, de nem történtek lépések annak lezárására. A kérdéses nyomornegyed házai pedig illegális telepítésnek számítottak, ugyanakkor a hatóság által ismert és megtürt módon.

Az élethez való jog jelentette az elsődleges hivatkozási alapot, amellyel kapcsolatban a Bíróság egyebek között megállapította: „A Konvenció 2. cikk 1. bekezdésének első mondata értelmében az államnak nem csupán tartózkodnia kell az élet szándékos és illegális kioltásától, hanem biztosítania is kell az élethez való jogot általában, és egyes jól meghatározható esetekben mindez olyan kötelezettséget is ró az államra, amely szerint tegye meg azokat az intézkedéseket, amelyek a joghatósága alatt élők életének megóvásához szükségesek." (62.) A hatóságok jelen esetben tudtak vagy legalábbis tudhattak volna az életet is fenyegető veszélyröl, és „elmulasztották megtenni azokat az intézkedéseket, amelyek hatalmukban álltak volna, és amelyek révén a koc-

53 Ahunbay és Tsai v. Törökország (6080/06), 21. 06. 2016.

54 Cordella and Others v. Italy (application nos. 54414/13 and 54264/15), 24. 01. 2019.

55 Öneryildiz v. Turkey (application no. 48939/99), 2002. június 18-i ítélet. 
kázatok elkerülhetők lettek volna". (63.) Mindezek összefüggésbe hozhatók a környezeti kérdésekkel. „Ezzel összefüggésben emlékeztetni kell arra, hogy az európai elvárások legutóbbi fejlődése e tekintetben aláhúzza a nemzeti közigazgatási hatóságok kiterjedt figyelmének szükségességét a környezeti területen, különösen olyan létesítmények esetében, amelyek a települési hulladék tárolására szolgálnak és amelyek működtetése jelentős kockázattal jár.” (64.) A hatóságok magatartása esetében „nem indokolt különbséget tenni a tevékenység, mulasztás vagy »gondatlanság« között, amikor azt vizsgáljuk, megfeleltek-e kötelezettségeiknek". (65.)

Ez az eset a többi hasonlóra nézve is meghatározó maradt, érvelési rendszere megállta az idők próbáját. Alább a 8. cikkhez hasonlóan röviden utalok egyes jellemző esetekre, ugyancsak - a határozathozatal szerinti - időrendben:

- Földcsuszamlások és ezek következtében halállal is járó következmények jelentek meg egy oroszországi (Tynauz) esetben ${ }^{56}$ (Budayeva). Az EJEB itt is - ahogy máshol is - utalt arra, hogy a gondolatmenet, a követelmények az állam vonatkozásában a 2. és a 8. cikk esetében (133.) „nagyban fedik egymást”. Az államnak számos lehetöség áll rendelkezésére, amelyek között választhat. A hatóságoknak tudatában kell lenniük, milyen veszélyes a terület, és gondoskodni kell megfelelő monitoringról is, hogy jelezni tudják a várható veszélyeket, hogy fel tudjanak készülni. Az EJEB érdemi vizsgálatot is folytatott, mert a hatóságok ezt nem tették meg.

- A máltai hajógyári munkások panaszában ${ }^{57}$ (Brincat) ugyancsak találkozik a 2. és 8. cikk. A munkások az 1950-es évek és a 2000-es évek eleje között erős azbesztszennyezésnek voltak kitéve. Ismét felmerül az állam pozitív irányú felelőssége, amely egyebek között a megfelelő jogi és igazgatási keretek megteremtésére terjed ki, valamint a gyakorlati intézkedésekre és a megfelelő információra. Természetesen itt is, ahogy minden más esetben az állam mérlegelési szabadságát emelik ki. Számos lehetősége lett volna az államnak, amivel nem élt. Ezzel a 2. cikkel kapcsolatos pozitív kötelezettségeit szegte meg azok irányában, akik már nem élnek. A 8. cikk pedig azokra terjed ki, akik ma is élnek.

- Elviekben jelentős egészségkárosodás - leukémia - lehet az Ilva üzem szenynyezéseinek következménye ${ }^{58}$ (a Cordella-ügyben is ez az üzem volt a felelős), ami elviekben alapot adhat a 2. cikk alkalmazására, de a panaszos nem tudta bizonyítani, hogy a tudomány jelenlegi állása alapján az állami szervek súlyos mulasztást követtek volna el (Smaltini).

- Törökország egy földrengésveszélyes övezetében épült ház egy esemény következtében összedőlt, 9 halott maradt a helyszínen ${ }^{59}$ (Özel). A következtetés

56 Budayeva and Others v. Russia (applications nos. 15339/02, 21166/02, 20058/02, 11673/02 and 15343/02), 29. 09. 2008.

57 Brincat and Others v. Malta (applications nos. 60908/11, 62110/11, 62129/11, 62312/11, and 62338/11), 24. 07. 2014.

58 Smaltini v. Italy (application no. 43961/09), 16. 04. 2015.

59 Özel and Others v. Turkey (applications nos. 14350/05, 15245/05 and 16051/05), 17. 11. 2015. 
elsősorban az, hogy a természeti katasztrófák esetében is van az állam magatartására nézve elvárás, a felkészítés, tájékoztatás, ellenőrzés, például a rendezési tervek felügyelete, amely akár az engedélyezési folyamatokra is kiterjed (építési engedély). Ez akkor is alapvető kérdés, ha amúgy eljárási okokból érdemben nem foglalkoztak az üggyel.

\subsection{Az 1. sz. jegyzökönyv 1. cikke}

Az Öneryildiz-esetben az élet mellett a birtoklás kérdése különös jelentőségre tesz szert, hiszen az áldozatok egyfajta „bádogvárosban” laktak a lerakó körül, tehát jószerivel háznak sem nevezhető építményekben, amelyeket nem saját tulajdonú telekre húztak fel. A Bíróság e tekintetben is - a birtoklási módok közötti bármiféle megkülönböztetés nélkül - az állam pozitív kötelezettségeit emelte ki (145.), méghozzá a következők szerint: „Annak megítélése terén, hogy létezik-e ilyen pozitív kötelezettség, tisztességes egyensúlyt kell teremteni a közösség érdekei és az egyén érdekei között. [...] Ez a kötelezettség kétséget kizáróan fennáll, többek között akkor, amikor közvetlen kapcsolat van azon intézkedések között, amelyet a kérelmező joggal vár el a hatóságoktól és a birtokláshoz való jog gyakorlása között." A Bíróság következtetése szerint „a közigazgatási hatóságok mulasztásainak láncolata, amelyek a metángáz robbanás kockázatának elkerülésére lettek volna szükségesek és a kérdéses földcsuszamlás ugyancsak ellentétben áll az 1 . sz. Jegyzőkönyv 1 . cikke szerinti a jog "gyakorlati és hatékony « védelméhez szükségesek. Ez a helyzet a nyugodt »birtoklás« jogának egyértelmű megsértése, és a kérelem első részének vizsgálati céljai szerint, megfelel a »beavatkozás « fogalmának." (146.)

A birtoklás - itt tulajdon - kérdése a Budayeva esetben is napirendre került. Amiért ez az ügy kiváltképpen tanulságos, az a különbségtétel az érintett alapjogok között, mégpedig a birtokláshoz való jog egyértelmüen kisebb jelentöségünek tekinthetö, mint az élethez való jog. „175. Ezért a Bíróság úgy véli, hogy a jelen ügy céljainak megfelelően különbséget kell tenni az Egyezmény 2. cikkével, illetve az 1. sz. jegyzőkönyv 1. cikkével kapcsolatos kötelezettségek között. Amíg az élethez való jog alapvető fontossága megköveteli, hogy a 2. cikkel kapcsolatosan megjelenő pozitív kötelezettségek értelmében minden meg kell tenni, ami a hatóság hatalmában áll a természeti katasztrófa elkerülése érdekében ezen jog védelmére, addig a békés birtokláshoz való jog nem abszolút jog, ezért nem terjedhet tovább, mint ami az adott körülmények között észszerű. Ennek megfelelően a hatóságok mérlegelési lehetősége is nagyobb, mint az emberi életek megvédése esetében." Ebből eredően lesz majd a kártérítés összege is meghatározható.

\section{Az Európai Szociális Karta és a környezet}

Az Európai Szociális Karta az Egyezmény által közvetlenül nem érintett kérdést, az egészség védelmét állithatja csatasorba a környezeti érdekek védelmére. Az Egyezmény szól 
az élethez való jogról, ami több, mint az egészség, illetve az otthon, a magán- és családi élet védelméről, ami pedig jelenthet átfedést, de mégis kissé más, mint az egészség, tehát voltaképpen kiegészíti a másik kettőt, betölti az ürt talán éppen a legfontosabb kérdéssel.

\section{I. rész 3. „Minden dolgozónak joga van a biztonságos és egészséges munkafeltételekhez."}

(Ezt megismétli a 3. cikk is.)

11. Cikk Az egészség védelméhez való jog

„Az egészség védelméhez való jog tényleges gyakorlásának biztosítására a Szerződő Felek kötelezettséget vállalnak arra, hogy akár közvetlenül, akár a köz- vagy magánszervezetekkel együttműködve megfelelő intézkedéseket tesznek."

A körülmények tisztázásaként annyit mindenképpen érdemes megjegyezni, hogy a Kartát 1961-ben írták alá, hatályos szövege az 1996-os módosítás eredménye. Az Egyezménnyel ellentétben a Karta nem feltétele a Tanács tagságának. Fontos eleme a Bizottság, amelyik egyfajta kiegészítője az EJEB-nek - jelentősen eltérő hatáskörrel természetesen -, részben ellenőrzi a Karta végrehajtását, részben panaszokkal foglalkozik. Ez utóbbi lehetőség alapja az 1995-ben aláírt és 1998-ban hatályba lépett jegyzőkönyv a kollektív igényekről (panaszokról), amely - ellentétben az EJEB-bel, ahol kizárólag egyéni panaszok vizsgálatára kerülhet sor - egyes NGO-któl fogad panaszokat, a részes állam Kartát sértő magatartásaival kapcsolatban. A végső szót a Miniszterek Bizottsága adja ezen ügyekben is.

A Szociális Ügyek Bizottsága két jelentős, valóban előremutató ügyben hozott figyelemre méltó döntést. Mindkettő Görögországgal volt kapcsolatos, és mindkettő azonos eredményre jutott, sőt egyre több lépést tettek az elfogadás irányában.

A Marangopoulos-ügyben ${ }^{60}$ a kiváltó ok egy hosszú ideje múködő lignitbánya, és a hozzá kapcsolódó, a lignitet fütőanyagként használó erőművek kérdése, mindkét esetben azon okból, hogy nem vették kellö módon figyelembe a környezetre ható következményeket, illetve ezeket nem mérsékelték. A Bizottság alaposan körüljárta a kérdést, kiváltképpen nagy figyelmet forditott az EU környezeti jogi rendelkezéseire, illetve a kapcsolódó joggyakorlatra, valamint a klímavédelemmel kapcsolatos nemzetközi elvárásokra. Ez az ügy volt az első, amely hangsúlyt adott a környezetvédelemnek, kiindulva abból, hogy „194. A Bizottság rávilágít, hogy a Karta egy élő szervezet, amelynek célja a jogok védelme, nem csupán elméleti szinten, hanem tényszerủen is [...] Ennek megfelelően a Kartában megjelenő jogokat és szabadságokat az aktuális viszonyokra vonatkoztatja.” A következmény tehát: „195. A Bizottság ennek következtében figyelembe vette azon növekvő számú kapcsolatokat, amelyeket azon államok, amelyek tagjai a Kartának és más nemzetközi szervezeteknek, manapság megteremtenek az egészség és az egészséges környezet védelme között, amiért a Karta

60 Marangopoulos Foundation for Human Rights (MFHR) v. Greece, Complaint no. 30/2005, Adoption: 6. December 2006. 
11. cikkét (az egészség védelméhez való jog) úgy értelmezik, mint ami magába foglalja az egészséges környezethez való jogot." A Karta 11. cikke és az Egyezmény 2. cikke között olyan viszonyt lehet felfedezni, amely egymást szervesen kiegészíti (202.).

A határozat számos alapvető kérdést tárgyal, amelyeket itt - helytakarékossági célból - nem kívánok részletesen elemezni, mindenesetre kiterjedt felsorolást ad a nemzeti hatóságok kötelezettségeire nézve (203.), megállapítja az is, hogy a fentiek mellett a Karta 3. cikke, ami a biztonságos és egészséges munkakörnyezetre vonatkozik - tegyük hozzá, hogy ez egy szűkebb kört jelentő védelmi tárgykör, mint az egészséges környezet - az ember integritása védelmének egy része. Mindezek számos elemmel segítik elő az egészséges környezethez való potenciális jog majdani alapozását.

A 2011-es ügyben $(F I D H)^{61}$ az Asopos folyóban elhelyezett hulladék és az abból származó szennyezés emberi egészségre gyakorolt hatásait panaszolta fel, ugyancsak a 11. cikkre hivatkozással. Ami különösen lényegi szempont volt ebben az ügyben is, hogy a Bizottság kifejezetten részletesen foglalkozott EU-joggal és az uniós szervek - így a Bíróság - eljárásaival is, amelyeket kiemelten fontos hivatkozási alapként kezelt. Mindebben a Bizottság teljes mértékben támaszkodik a megelőző, fentebb ismertetett döntésre, amelynek világos konklúziója tehát: „51. A Bizottság szerint a Karta 11. cikkében biztosított egészséghez való jog, amelyik kiegészíti az Emberi Jogok Európai Egyezménye 8. cikkét (a magán- és családi élet tiszteletben tartásához való jog), amint azt az Emberi Jogok Európai Bírósága értelmezte. Ez utóbbi értelmében a súlyos környezetszennyezés hátrányosan befolyásolhatja az egyének jólétét, így megvalósítja a 8. cikk sérelmét."

Mindezek és az itt meg nem ismételt értelmezés mellett, ebben a határozatban megjelenik egy fontos újabb elem, amely a környezetvédelem jogi kérdéseinek egyik legjellemzőbb differentia specificája, ez pedig az elővigyázatosság elve. „150. Ami az egészséghez való jog védelmének érvényesülését jelenti, a Bizottság figyelembe veszi, hogy azon esetekben, amikor az előzetes tudományos értékelés arra utal, hogy észszerủen feltételezhető, hogy az emberi egészségre várhatóan káros hatások jelennek meg, az államok elővigyázatossági intézkedéseket kell tegyenek, a 11. cikkben jelzett magas szintủ védelemnek megfelelően.” A döntés 153. pontja pedig megállapítja a jogsértést, az ott felsorolt indokokra tekintettel.

A bizottsági határozatok kapcsán számos kapcsolódó kommentárt találhatunk, közülük emelek ki egyet: ${ }^{62}$ „Ami kiváltképpen figyelemre méltó a bizottsági érvelésben az az »egészséges környezethez való jog « kifejezett elismerése, ami az egészséghez való jogon belül jelenik meg és összefüggés az EJEB élethez való jogával.” „A Bizottság határozata ezért úgy értékelhető, mint a környezeti ügyek előremutató módon történő befogadása az európai emberi jogi intézmények részéről."

61 International Federation for Human Rights (FIDH) v. Greece, Complaint no. 72/2011 European Committee of Social Rights, Adoption: 23 January 2013.

62 Mirja Trilsch: European Committee of Social Rights: The right to a healthy environment. International Journal of Constitutional Law, 7. (2009), 3. 529-538. 
Ez év februárjában a grúz elnökség által 2020. februárban rendezett magas szintű konferencián elhangzott bizottsági elnöki hozzászólás ${ }^{63}$ leszögezi annak fontosságát, hogy „lépéseket kell tenni az Európai Szociális Karta mellett olyan jegyzőkönyv megfogalmazására, amelyik elismeri (ahogy az amerikai kontinensen már megtörtént) a környezeti kérdések emberi jogi védelem alá helyezését. Ebben a tekintetben úgy vélem, hogy az Európai Szociális Karta lenne erre a legalkalmasabb jogi keret, inkább, mint az Emberi Jogok Európai Egyezménye, amelyik közismerten a polgári és politikai jogokra koncentrál egy »egyéni jogvédelmi« megközelítéssel.” Megindult tehát egy olyan mozgalom, hogy a Szociális Karta vigye el a pálmát, amelyre mindenképpen nagyobb esély mutatkozik, mintsem az Egyezmény módosítására.

\section{Az eljárási jogok útján}

A környezethez való jog érvényesülésének megoldási módjai, a kérdéses jog elhelyezkedésének minél egyszerübb megoldásai a kezdetektől foglalkoztatják a jogirodalmat, és a lehetőségek nem is igen változtak az évek során. Egy ma is ugyanúgy aktuális - hiszen a nemzetközi jog adós maradt a kodifikálással - tanulmány ennek kiváló összegzését adja: ${ }^{64}$ „Három megközelítési módról van szó: először a meglévő jogokat mobilizálni környezeti célokra; másodszor környezeti szempontból újraértelmezni a meglévő jogokat; és harmadszor, kifejezetten környezeti szempontú jogokat alkotni." Ezen belül a harmadik opció esetében is két megoldás lehetséges: az eljárási jogok útja és az anyagi jogi lehetőség. Az előbbi egyszerűbb választás: „[N]agyon nehéz egyetlen pontos megfogalmazását adni a megfelelő környezethez való anyagi jognak. Ezért a rugalmasabb, áttekinthetőbb, célra-irányozott megközelítés, ha az embereket felvértezzük erőteljes eljárási jogokkal, amelyek erősíthetik a nyílt és alapos érdemi vitákat."

Az eljárásjogi megközelitést másképpen a társadalmi részvétel elemeinek tekinthetjük, amely évtizedek óta folyamatosan része a nemzetközi és nemzeti környezeti jognak. Ezt mi sem bizonyítja jobban, mint a 1992-es Riói Nyilatkozat, ${ }^{65}$ amely 10. elvében már adottnak tekinti, hogy: „A környezeti ügyeket a legjobban az összes érdekelt állampolgár részvételével a megfelelő szinten lehet kezelni.” ${ }^{66}$ A társadalmi

63 Intervention by Giuseppe Palmisano, President of the European Committee of Social Rights. Highlevel Conference "Environmental Protection and Human Rights", Organised under the aegis of the Georgian Presidency of the Committee of Ministers of the Council of Europe, Strasbourg, 27 February 2020.

64 Anderson, Michael R.: Human Rights Approaches to Environmental Protection: An Overview, in Human Rights Approaches to Environmental Protection 2-10, (A Boyle - M. Anderson ed. 1996), közreadta: Environmental Protection and Human Rights, Donald K. Anton and Dinah L. Shelton Cambridge University Press, 2011. 134-137.

65 Részletes elemzés: Az ENSZ Környezet és Fejlődés Konferenciájának Magyar Nemzeti Bizottsága: Az Egyesült Nemzetek Szervezetének Környezet és Fejlödés Konferenciája: Tények és adatok. Budapest, 1992. magyar nyelvű szövege: Riói Nyilatkozat a Környezetről és a Fejlődésről.

66 A 10. elv folytatása: „Nemzeti szinten minden egyénnek biztosítani kell a megfelelő hozzáférést a környezetre vonatkozó információkhoz, melyekkel a közhivatalok és a hatóságok rendelkeznek; 
részvétel, így az eljárási jogok hatékony érvényesítése érdekében Európában, az ENSZ EGB égisze alatt, nem sokkal később megalkották a 2001. évi LXXXI. törvénnyel hazánkban is kihirdetett „a környezeti ügyekben az információhoz való hozzáférésről, a nyilvánosságnak a döntéshozatalban történő részvételéről és az igazságszolgáltatáshoz való jog biztosításáról" szóló, Aarhusban, 1998. június 25-én elfogadott egyezményt. Ennek 1. cikkelye, a környezethez való jogra is utalva egyben, kimondja és egyben a fenti 10. elv lényegi tartalmát is megismétli: „A jelen és jövő generációkban élő minden egyén azon jogának védelme érdekében, hogy egészségének és jólétének megfelelő környezetben éljen, ezen Egyezményben Részes valamennyi Fél garantálja a nyilvánosság számára a jogot az információk hozzáférhetőségéhez, a döntéshozatalban való részvételhez és az igazságszolgáltatás igénybevételéhez a környezetvédelmi ügyekben." ${ }^{67}$

Az Egyezmény, a fentiekben felsorolt cikkeinek bizonysága szerint sokkal közvetlenebbül foglalkozik ezekkel az eljárási típusú jogokkal - még ha természetesen nem „társadalmi részvételi jogok a környezetvédelemben” címszó alatt is -, mint magával a környezeti jogokkal, igazolva azt az előzetes feltételezést, hogy sokkal egyszerübb az eljárási jogokat megfogalmazni, mint érdemi megközelitést megformázni a környezeti jogok terén. A következő néhány példában nem az Egyezmény cikkei alapján, hanem a társadalmi részvétel előbb bemutatott három pillérére alapozva mutatom be az EJEB vonatkozó jogértelmezését:

- Az információval kapcsolatos jogok között kiváló példát szolgáltat a Guerra és társai eset, ${ }^{68}$ ahol a hatóságok nem informálták megfelelően a társadalmat az üzem potenciális káros hatásairól, ezzel a 8. cikket sértették meg, mert az ott lakók nem lehettek képesek felmérni azokat a kockázatokat, amelyek a közelben lakás miatt rájuk hárultak. „60. [...] A kérdéses esetben a kérelmezők, egészen a mútrágyagyártás 1994-es megszűnéséig várnak arra, hogy megfelelő információt kapjanak, ami alapján fel tudják mérni annak kockázatát, ha ők és családjuk tovább élnek Manfredoniában, egy olyan városban, amely különösen kitett az üzem baleseti kockázatának."

- A Tatar-ügy ${ }^{69}$ a tiszai cianidszennyezés miatt ismert Baia Mare bánya esetéhez kapcsolódó jogi igényeket tárgyalta, sikerrel. Az EJEB szerint a 2000. januári baleset kapcsán a város polgárait értesíteni kellett volna, feltárva a környezetegészségügyi kockázatokat (101.), és a 8. cikk megsértésének egyik oka ezen

beleértve a veszélyes anyagokra és az állampolgárok közösségeit érintő tevékenységekre vonatkozó információt; és lehetővé kell tenni a döntéshozatali folyamatban való részvételt. Az államok segítsék elő és bátorítsák a lakosság tudatosságát és részvételét azzal, hogy széles körben hozzáférhetővé teszik az információkat. Hatékony hozzáférést kell biztosítani a bírósági és igazgatási eljárásokhoz, beleértve a jóvátételt és helyreállítást."

67 Számos információt és részletet találhatunk az Egyezmény kiadványában: United Nations Economic Commission for Europe: The Aarhus Convention. An implementation guide. 2014.

68 Guerra v. Italy (116/1996/735/932), 1998.

69 Tătar c. Roumanie (Requête no 67021/01), 27 janvier 2009. 
információ elmaradása, ahogyan vizsgálatokat sem végeztek időben a következményekről, illetve később azok eredményeit sem ismertették (113.).

- A már ismert Öneryildiz-esetben ${ }^{70}$ kiemelték, hogy a kormányzati szervek tudtak a lerakó környékének nyomornegyedeiről (Ümraniye), azt megtűrték, és nem akadályozták meg, hogy a hulladéklerakó közelében telepedjenek le, sőt inkább elősegítették az illegális telep működését (85.). Mindeközben a hatóságok a legkisebb erőfeszítéseket sem tették meg, hogy az érintetteket a veszélyekről felvilágosítsák (86.).

- A Budayeva-ügy ${ }^{71}$ sem marad adó az információ fontosságának kérdésével, hiszen az állam pozitív irányú kötelezettségei tartalmi és eljárási kérdésekre is kiterjednek, így az életveszélyes katasztrófahelyzetről való megfelelő tájékoztatásra (131.).

A döntéshozatali részvétel összefüggésében is vannak tanulságok:

- A Hatton-ügy ${ }^{72}$ számos tanulsága közül az egyik, hogy a kormányzati szerveknek megfelelő vizsgálatokat és tanulmányokat kell folytatni (és ez meg is történt), hogy megfelelő alapozást kapjanak az érdekek közötti megfelelő súlyozáshoz (128.).

- A Tatar-ügyben az engedélyezési folyamatban sem adtak megfelelő lehetőséget, sem a megismerésre, sem a döntésekbe való beleszólásra, nem voltak megfelelő tanulmányok és vizsgálatok sem, illetve minden döntéssel kapcsolatban biztosítani kellett volna a jogorvoslati jogokat is (88.).

- Az Öneryildiz-esetben hangsúlyossá vált, hogy olyan jogi és igazgatási kereteket kell kialakítani, amely alkalmas arra, hogy megfelelő védelmet nyújtson az életet fenyegető veszélyek ellen (89), beleértve az engedélyezési, biztonsági, ellenőrzési feladatokat is, és ezekkel kapcsolatban eljárási jogokat is kell biztosítani (90.).

A független fórumokhoz fordulás lehetösége - ez föként bíróságot jelent - is sok esetben erősen hiányos.

- Az Öneryildiz-esetben a fenti folytatásaként a már említett jogi és igazgatási feltételek mellett a megfelelő jogorvoslati lehetőségek - bírói vagy igazgatási - sem maradhatnak el (91.). A bírósági lehetőségeknek az eljárás megfelelő kivizsgálásához független és pártatlan kereteket kell biztosítaniuk - akár a büntetőeljárásig terjedően (94.).

- A Taskin-ügy ${ }^{73}$ a Tatarhoz némileg hasonlóan aranybánya engedélyezésével foglalkozott Bergamában (Izmir), amely bánya szennyezése és zaja sokak életét

70 Öneryildiz v. Turkey (application no. 48939/99), 2002. június 18-i ítélet.

71 Budayeva and Others v. Russia (applications nos. 15339/02, 21166/02, 20058/02, 11673/02 and 15343/02), 29. 09. 2008.

72 Hatton v. UK (Application no. 36022/97), 8 July 2003.

73 Taşkin and Others v. Turkey (Application no. 46117/99), 10 November 2004. 
megnehezítette. A már ismert információs jogok hangsúlyozása mellett kifejezetten követelményként merült fel a döntések, tevékenységek és mulasztások ellen a bírósághoz fordulás lehetősége (119.). Az is lényegi kérdéssé vált, hogy a végül eljárós Izmiri Közigazgatási Bíróság döntéseit megfelelő határidőben nem hajtották végre a hatóságok (137.).

\section{Következtetések}

A „nagy”, 70 éven túljutott vagy most évfordulót ünneplő emberi jogi egyezmények nem tartalmaznak semmilyen értelemben sem közvetlenül környezettel kapcsolatos jogokat. Ez még akkor is igaz, ha a későbbi egyezségokmányok vagy karták is vizsgálatunk tárgyát jelentik, hiszen ezekkel kibővítve sem változott a helyzet. A kulcs legegyszerűbben az időzítés, a sok évtized. Ugyanakkor a sok évtized önmagában nem ad feltétlenül magyarázatot arra, miért is nem módosítják, vagy jegyzőkönyvvel vagy anélkül egészítik ki ezen dokumentumokat, holott erre nézve számos lépés jutott el az ajánlattételhez, de nem tovább. A probléma tehát ennél sokkal összetettebb:

a) Ennek csak egyik, legegyszerübb oka lehet az, hogy nem rugalmas az egyezmények struktúrája, nehezen engedi a kiegészítéseket.

b) A környezetre vonatkozó érdemi követelmények, anyagi jogi elvárások egyszerủ és világos megfogalmazásának nehézségei sem könnyítenek a helyzeten, különösen annak ismeretében, hogy még ma is vannak szkeptikusok, a környezeti hatások súlyát kisebbítők.

c) A környezethez kapcsolódó jogok eleve nehezen határozhatók meg egyéni jogokként, hanem sokkal inkább kollektív jogok, ami például az európai Egyezményben eleve kizáró ok.

d) Arról nem is beszélve, hogy ezek a kollektív jogok egész generációkat is felölelnek - inter- és intragenerációs jogokról beszélünk -, ahol a jövő nemzedékek sem maradhatnak ki a jogosultak sorából, ami kiváltképpen bonyolult kérdés, teljes személetváltást igényel.

e) És - különösen a jövő generációkra gondolva - egyre inkább a jogok kötelezetti oldala felől kell közelíteni, alkalmanként a jog erőltetése értelmezési nehézségeket okozhat.

f) Végül nem feledkezhetünk meg arról, amiről eddig nem is ejtettünk szót, hogy a jogok gondolati körébe az ember, a természetes személy mellé mindinkább be kell emelni a környezetet, mint védett jogtárgyat, ennek is nem egy esetben esztétikai szempontjait, ami ugyancsak további nehézségekkel terheli az „emberi” joggá minősítés lehetőségét.

Az európai Egyezményre is mindez igaz, de van egy komoly különbség, ami ebben az esetben feltétlenül előnyt jelent, mégpedig elsősorban az EJEB, amelynek müködése lehetőséget ad az esetleges párhuzamok, analógiák viszonylagos rugalmassága révén az egyes jogok kiterjesztett értelmezésére. Ehhez még a Karta is hozzászámít, 
noha annak tényleges hatóköre - például a kevesebb számú elfogadás okán - korlátozottabb. Pillanatnyilag mindez nem elég ahhoz, hogy a fent felsorolt nehézségeken úrrá tudjunk lenni. Az EJEB és a Karta Bizottsága sem lépheti túl tehát saját korlátait. Különösen a 2. cikk, a 8. cikk, az 1. jegyzőkönyv 1. cikk és a Karta cikkeit (3. és 11.) együttesen szemlélve az alábbiak a legfontosabb összetevők: ${ }^{74}$

- Az Egyezmény egyéni jogokat véd, tehát sem közösségek, sem a környezet képviseletében nem járhatnak el mások, az viszont nem kizárt, hogy egyének közösen lépnek fel, de akkor is egyenként vizsgálják a befogadhatóságot. Környezethez való jog semmilyen formában nem kerül szóba, a gyakorlat is világossá tette, hogy nincs ilyen jogosítvány, minden esetben keresni kell az egyéni jogsérelmet.

- Az Egyezmény szubszidiárius módon jelenhet meg csupán, amikor az állami szervek hiányosságai, mondhatni alkalmatlansága bizonyossá válik. Addig az Egyezményre semmiképpen sem lehet, még a következőkben leírt korlátozott módon sem hivatkozni, a mérlegelési jog kiterjedtsége nem teszi lehetővé.

- A Karta viszont nem foglalkozik egyéni kérelmekkel, hanem az arra jogosított társadalmi érdekképviseleti szervek járnak el, általában nagyobb közösséget érintő ügyekben, de a környezet mint védett jogtárgy ide sem illeszthető be.

- A 2. cikk alkalmazásához kifejezetten életellenes cselekménynek és végzetes következménynek kell történnie, itt tehát nem lesz érdemben vizsgálandó szempont a súlyosság, mert az már adott. A halálos következmény miatt ez talán az értelmezés legszűkebb keresztmetszete.

- A 8. cikk alkalmazása során ki kell mutatni a magán- és családi élet vagy az otthon közvetlen sérelmét, amely tehát az egyénre vonatkoztatható. Ez a sérelem származhat környezeti terhekből, szennyezésekből, de csak akkor jöhetnek ezek számításba, ha az átlagostól eltérő, a mindennapi élet terhelésein túlmutató, súlyos, jelentős környezeti szennyezés (a legtágabb értelemben vizsgálva) volt a kiváltó ok. Ennek megfelelően a folyamatos, de veszélyes vagy káros terhelések, szennyezések kívül esnek az EJEB vizsgálati körén, ami azt jelenti, hogy éppen a legjellemzőbb, leggyakoribb negatív környezeti történéseket, eseményeket nem tudjuk vizsgálni. Igaz, a súlyosság nem abszolút fogalom. Ezzel együtt is a 8. cikk adja a legszélesebb védelmi kört.

- A szennyezés szüken vett fogalmán túl a nyugodt, csendes környezet védelme, illetve sérelme is alapot adhat az eljárásra, amennyiben arra egyébként a már leírt feltételek érvényesülhetnek.

- Az 1. sz. jegyzőkönyv 1. cikkének alkalmazására érdekes duális szemlélet irányadó: amíg a birtokláshoz való jog tekintetében lazábbak az elvárások, azok a tényszerű birtoklást és nem a jogszerűt védik csupán, addig a mérce ebben

74 Egy akkor futó ügy (Dubetska v. Ukrajna - Application No. 30499/03, Judgment of 10 February 2011) kapcsán összegezte hasonlóan a 2. és 8 . cikkhez kapcsolódó kérdéseket cikkében Malgosia Fitzmaurice: The European Court of Human Rights, environmental damage and the applicability of Article 8 of the European Convention on Human Rights and Fundamental Freedoms. Environmental Law Review, 13. (2011), 2. 108-109. 
az esetben magasabb, a mulasztásoknak e körben nagyobb súlyúaknak kell lenniük, mert a 2 . cikk vagy a 8 . cikk ebben a tekintetben némileg enyhébb, a védett jogtárgy nagyobb fontossága miatt.

- Minden esetben az állam esetleges közvetlen cselekvései mellett, vagy sokkal inkább azok helyett, az állam nem cselekvése, mulasztása, a jogok elmaradt védelme jelenti a jogsértést - nem tette meg, amit megtehetett volna, ami módjában volt. Ehhez járul a már említett szubszidiáriusság.

- Az állam széles körű mérlegelési jogkörrel, mozgástérrel rendelkezik részben abban a tekintetben, mit tesz a mulasztás elkerülése érdekében, de különösen az egyéni és a közösségi érdek közötti megfelelő egyensúly mérlegelésében. Így tehát a mérlegelés, súlyozás kisebb anomáliái bocsánatos bủnnek számítanak, ez kevésbé igaz az élet sérelme esetében, ott magasabb a mérce.

- Az állam cselekvéseit, pozitív kötelezettségeinek lehetőségeit több jogesetben tételesen kifejtik, a jogalkotástól a megfelelő vizsgálatok elvégzésén át az engedélyezésig, ellenőrzésig vagy éppen a szankcionálásig terjedően.

- A gazdasági érdekek és a környezeti érdekek súlyozása során a prioritás a környezeté, ugyanakkor ez távolról sem teljes, hiszen elismerik a nemzetgazdasági szempontokat, mint mégis az egyensúly eltérítésére alkalmas tényezőt.

- Az eljárási jogok esetében a helyzet egyszerủbb, hiszen valójában teljes körben érvényesülnek, de a környezeti elem ehhez nem igazán ad sok újat, itt bevált gyakorlati megoldások mutatkoznak az információhoz jutás, a döntéshozatali részvétel vagy éppen a jogorvoslat és ott is a független - többnyire bírói - fórum tekintetében.

- A Karta joggyakorlata viszont elismeri a környezethez való jog létét, az egészséghez való jogon keresztül, tehát mégiscsak korlátozottabb módon, mint ami a teljes környezeti jogi megközelítéshez elegendő lenne. Az „egészséges környezethez való jog" vélhetően főként környezet-egészségügyi problémákat takar. Viszont pluszként megjelenik az elővigyázatosság elve is.

A gyakorlat így előbbre van, mint a szabályozás, amelyik a közeli jövőben aligha fogadja be a - bármilyen jelzős szerkezettel is ellátott - környezeti jogot. Az nem kizárt, hogy végül erre a Kartának nagyobb esélye lesz, mint az Egyezménynek, bár ott is csak jegyzőkönyv formájában. Ez nyilván nem képes átfogni a kérdéses jog valós tartalmát, szükségképpen korlátozott marad, mind lényegét, mind hatókörét illetően, tehát nem jelent valós megoldást.

\section{Irodalomjegyzék}

Anderson, Michael R.: Human rights approaches to environmental protection: An overview. In Alan Boyle - Michael Anderson (eds.): Human rights approaches to environmental protection. 1996. 2-10.

Anton, Donald K. - Dinah L. Shelton: Environmental protection and human rights. Cambridge, Cambridge University Press, 2011. Online: https://doi.org/10.1017/CBO9780511974571 
Buergenthal, Thomas: The Evolving International Human Rights System. American Journal of International Law, 100. (2006), 4. 783-807. Online: https://doi.org/10.1017/s0002930000031894

Carelli, Francesco: Enforcing a right to a healthy environment in the ECHR System: The 'Cordella v. Italy' case. Rivista Giuridica AmbienteDiritto.it, (2019), 4. 1-14.

Council of Europe: Manual on human rights and the environment. CoE Publishing, 2012. Online: www.echr.coe.int/Documents/Pub_coe_Environment_2012_ENG.pdf

Council of Europe Parliamentary Assembly: Doc. 12003. Drafting an additional protocol to the European Convention on Human Rights concerning the right to a healthy environment. 11 September 2009. Online: http://assembly.coe.int/nw/xml/XRef/Xref-XML2HTML-en. asp?fileid=12279\&lang=EN

Council of Europe Parliamentary Assembly: Recommendation 1885 (2009) Drafting an additional protocol to the European Convention on Human Rights concerning the right to a healthy environment. Online: https://pace.coe.int/en/files/17777/html

Council of Europe: Recommendation 1614 (2003): Environment and human rights. Online: https:// assembly.coe.int/nw/xml/XRef/Xref-XML2HTML-en.asp?fileid=17131\&lang=en

Az ENSZ Környezet és Fejlődés Konferenciájának Magyar Nemzeti Bizottsága: Az Egyesült Nemzetek Szervezetének Környezet és Fejlödés Konferenciája: Tények és adatok. Budapest, 1992. Online: http://real.mtak.hu/65984/1/1992Rioi_konferencia_1992_u.pdf

Environment and the European Convention on Human Rights, March 2020. Online: www.echr.coe. int/Documents/FS_Environment_ENG.pdf

European Court of Human Rights: Overview 1959-2018. Strasbourg, Council of Europe, 2019. Online: www.echr.coe.int/Documents/Overview_19592018_ENG.pdf

European Court of Human Rights: Protocols of the European Convention on Human Rights. 1950. Online: www.echr.coe.int/Documents/Archives_evolution_Convention_ENG.pdf

Fitzmaurice, Malgosia: Environmental degradation. In Daniel Moeckli - Sangeeta Shah - Sandesh Sivakumaran (eds.): International human rights law. Oxford, Oxford University Press, 2010. 590-610.

Fitzmaurice, Malgosia: The European Court of Human Rights, environmental damage and the applicability of Article 8 of the European Convention on Human Rights and Fundamental Freedoms. Environmental Law Review, 13. (2011), 2. 107-114. Online: https://doi.org/10.1350/ enlr.2011.13.2.122

Human Rights Comment: Living in a clean environment: a neglected human rights concern for all of us. Strasbourg, Council of Europe, 2019. Online: www.coe.int/en/web/commissioner/-/livingin-a-clean-environment-a-neglected-human-rights-concern-for-all-of-us

Az Igazságosság és Béke Pápai Tanácsa: Az Egyház társadalmi tanításának kompendiuma. Budapest, Szent István Társulat, 2007.

Intervention by Giuseppe Palmisano, President of the European Committee of Social Rights. Highlevel Conference "Environmental Protection and Human Rights", Organised under the aegis of the Georgian Presidency of the Committee of Ministers of the Council of Europe, Strasbourg, 27 February 2020.

Kravchenko, Svitlana- John E. Bonine: Human rights and the environment. Carolina Academic Press, 2008.

Leuprecht, Peter: Innovations in the European System of Human Rights Protection: Is enlargement compatible with reinforcement? Transnational law and contemporary problems. In Christina M. Cerna (ed.): Regional human rights system. Routledge, 2014. 313-336. 
Message of his Holiness Pope John Paul II for the celebration of the World Day of Peace. 1999. Online: www.vatican.va/content/john-paul-ii/en/messages/peace/documents/hf_jp-ii_mes_14121998_ xxxii-world-day-for-peace.html

Moeckli, Daniel - Sangeeta Shah - Sandesh Sivakumaran (eds.): International human rights law. Oxford, Oxford University Press, 2010.

A Nemzetközi Bíróság 1997. szeptember 25-i ítélete, Magyarország és Szlovákia jogvitája, Christopher Weeramantry alelnök különvéleménye. Online: www.icj-cij.org/en/case/92/judgments

Riói Nyilatkozat a Környezetről és a Fejlődésről. Online: www.nyf.hu/others/html/kornyezettud/ megujulo/Fenntarthato\%20fejlodes/A\%20Rioi\%20Nyilatkozat.htm

Shelton, Dinah L.: Regional protection of human rights. Oxford, Oxford University Press, 2010.

Trilsch, Mirja: European Committee of Social Rights: The right to a healthy environment. International Journal of Constitutional Law, 7. (2009), 3. 529-538. Online: https://doi.org/10.1093/ icon/mop019

United Nations Economic Commission for Europe: The Aarhus Convention. An implementation guide. 2014. Online: www.unece.org/fileadmin/DAM/env/pp/Publications/Aarhus_Implementation_Guide_interactive_eng.pdf

United Nations: Report on the United Nations Conference on the human environment. Stockholm, 5-16 June 1972. Online: www.un.org/ga/search/view_doc.asp?symbol=A/CONF.48/14/REV.1

Verschuuren, Jonathan: Contribution of the case law of the European Court of Human Rights to sustainable development in Europe. In Werner Scholtz - Jonathan Verschuuren (eds.) Regional Environmental Law: Transregional Comparative Lessons in Pursuit of Sustainable Development Edward Elgar Publishin Ltd., 2015. 363-385. Online: https://doi. org/10.4337/9781781951781.00021 